\title{
INTERACTIVE METHODS OF TEACHING OF FOREIGN LANGUAGES AND THEIR EFFICIENCY
}

\section{Artemenko A. I.}

\section{INTRODUCTION}

In modern society it is necessary to find a way to communicate in a new environment which is quite effective in establishing new relationships in a rapidly changing reality. Activity, independence, creativity, ability to adapt to rapid changes is personality traits and become the most important at the present stage of historical development and their formation requires the implementation of new approaches to the learning process ${ }^{1}$.

Social and economic changes that have taken place in the world in recent years make new demands on specialists in various fields of knowledge. The foreign language study plays a major role in forming professional qualities of future specialists. The implementation of the tasks requires the use of various methods in teaching foreign languages of students but the main methodological innovations involve the usage of interactive teaching methods.

Interactive training as a new methodological approach to the foreign language teaching gives a chance to solve communicative and cognitive tasks through foreign language communication. Interactive training activity involves the organization and development of dialogue speech aimed at mutual understanding, interaction, solving of innovative and general but significant tasks for every participant of the communication process.

The purpose of the interactive learning is to create the special conditions leading to the involvement of all students in the learning process when the participants can understand and realize everything that

\footnotetext{
1 Пишко О.П. Інтерактивні методи навчання як спосіб розвитку творчих здібностей учнів на уроках історії та правознавства. Народна освіта. 2021.
} 
happens, influence each other and make their own contribution having established the friendly and mutually supportive relationship ${ }^{2}$.

Foreign languages are very important nowadays. More and more people need foreign languages because they have an opportunity to use them in communication.

International relations are extended and strengthened through the exchange of is the matter of the communicative significance.

The interactive methods of the foreign language teaching include new forms, new principles, and new approaches in teaching process. Interactive training encourages and gives learners to create comfortable condition of learning and to develop creativity, intellectual and communicative abilities ${ }^{3}$.

The goal of the research is to analyze the interactive methods of foreign languages and their efficiency in teaching.

\section{The usage of interactive methods in teaching of foreign languages}

Analyzing the modern world we can acknowledge that it includes globalization and integration of the social development, economic, political, social and cultural spheres of human life. It includes transition from industrial production to the society of information technologies and then to the knowledge of the society; recognition of man as the highest value and purpose of the social development. New civilizational challenges are natural which make high demands on the personality of the specialist and his professionalism ${ }^{4}$.

The lecturer can increase the motivation of students to learn foreign languages explaining the importance of mastering of the foreign languages for their future activity.

Interactive methods provide the mechanisms to enable group members to explore the reasons they do their work and why it is important. They provide people with opportunities to consider and share the experiences, understandings and commitments that brought them to the group. Being in touch with these fundamental elements is critically important if group

${ }^{2}$ Eltanskaya E. Types of interactive Methods in Teaching English to Students of Economics. Current Issues of Linguistics and Didactics: The Interdisciplinary approach in Humanities : the 7th International and Scientific and Practical Conference. 2017. P. 100-105.

${ }^{3}$ Bakhredinovna M. The interactive methods and principles of foreign language teaching. International Journal on Integrated Education. 2020. Vol. 3. Issue I.

4 Ягоднікова В.В. Інтерактивні форми і методи навчання у вищій школі : навчально-методичний посібник. Київ : Персонал, 2009. 80 с. 
members are to be invested in the work of the group and motivated to make difficult decisions, resolve disagreements and apply energy which can be focused on their work. Interactive techniques can be used to help a group define its own dynamics and its own problems.

They can be divided into two groups: a) one of the parties is a lecturer with conversations included, discussions, seminars-discussions, seminars "questions -answer", discussions with provocative questions, consultations; b) communication takes place between students (conversations, discussions, round tables, brainstorming).

Brainstorming is a group solution of specific situations, business, role and didactic games, projects, communicative exercises depending on the purpose of the lesson and the forms of educational organization ${ }^{5}$.

Among the advanced methods in the modern educational process of learning interactive methods are based on the student-centered approach to development of the creative potential of the learner and improving communication skills ${ }^{6}$. The method of brainstorming is a method for solving communicative tasks in a short time. The essence of the method lies in the fact that it is necessary to express ideas, as much as possible in a short period of time, discuss them and classify them. This method is used to solve complex problems. The method of brainstorming can be used in various types of activities: in work with small and large training groups, individual work ${ }^{7}$.

Modern communicative methodology offers a wide introduction into the communicative process of active non-standard methods and forms of work for better conscious assimilation of material. In practice the following forms of work proved to be quite effective: individual, pair, group and team work ${ }^{8}$.

The usage of interactive teaching methods, which are not traditional, is important at the present stage of development of society, when you

${ }^{5}$ Січкарук O.I. Інтерактивні методи навчання у вищій школі : навчальнометодичний посібник. Київ : Таксон, 2006. 88 с.

${ }^{6}$ Kravchyna T. Types of interactive methods of teaching English for technical students. Open educational e-environmental modern University. № 5. P. 140-145.

7 Андрейко Л.В. Інтерактивні методи викладання іноземної мови: електронні засоби та дистанційні технології для навчання протягом життя. Тези доповідей міжнародної науково-методичної конференції (Суми, 13-14 листопада 2014 р.). Суми : Сумський державний університет, 2014. С. 89-92.

${ }^{8}$ Науменко У.В. Інноваційні методи навчання англійської мови у вищій школі в умовах модернізації. Молодий вчений. 2018. № 3.1 (55.1). С. 118-121. 
need to form a new type of personality, such as the person of the information society.

One of the main forms of improving the efficiency of the organization of the interactive process of learning of foreign languages is a didactic game.

We can admit that students depend on the usage of the modern information technologies in the learning process which can be used to support their communication and should be available in the understanding of the possibility of obtaining the necessary information at any time and provide the ability to individualize the process teaching taking into account the previous experience.

The interactivity is central to the social aspect of communication and it should be the primary goal of any communication process between the student and the lecturer which is necessary in order to develop and improve this process ${ }^{9}$.

Communication should be similar to natural communication in the social environment, in a life and culture of the people and the native speaker of the language. The similarity is ensured by such basic features as the directed and motivated nature of speech activity, the relevant relationships between those who communicate, the relevance of the topics and issues discussed to the age and mental characteristics (especially interests and level of development) of students. This nature of educational work provides an opportunity for successful transfer of foreign language communication.

The most important methods of teaching are interactive ones which are based on personality and oriented approach to the students. They can help not only to create communication but also think and react quickly improving communication skills. The introduction of active and interactive methods of teaching foreign languages is an innovative process of learning of foreign languages which can help form communicative abilities of students and the development of independence of their thinking and the formation of skills to work in small groups. The lecturer needs extensive methodological training for implementation innovative teaching methods as an effective pedagogical tool for optimal development and professional growth of students.

The research analyses the main points of interactive teaching, its actuality and practical value characterized by constant, active interaction of all participants in the educational process where a student and a

9 Сисоєва С.В. Інтерактивні технології навчання дорослих : навчальнометодичний посібник. Київ : ЕКМО, 2011. 324 с. 
lecturer are equal individuals in the process of study, modelling live situations, using role-playing games, mutual solution of different problems which are based on the analysis of the relevant circumstances and situations. The advantages of these methods involve full activity of the class, teamwork, friendly attitude to opponents, the opportunity to express own points of view, create a "situation of success", learning a big amount of the material in a short period of time and etc. In particular considerable attention is paid to the efficiency of using interactive methods in the process of students' communicative competence formation at the different stages of foreign languages such as introduction, development and conclusion ${ }^{10}$.

In the modern world one of the main directions in the development of the communication sphere is introduction of the modern information and communication technologies into the educational process. Electronic textbooks and interactive training programs are actively being created, automated training systems are being developed, virtual universities are being founded, and distance learning is being introduced into the learning process.

There is an imbalance between technical capabilities of modern teaching tools and the ability of lecturers to use them in teaching. We can admit that the development of information and communication technologies and the availability of the Internet access do not guarantee the quality of foreign languages teaching.

We can acknowledge that interactive methods that involve students in interactive activities in the classroom are becoming particularly effective nowadays.

Foreign languages are the most important means of learning cultures of the world. The main task of teaching foreign languages as a means of intercultural communication is that "languages must be studied together with the world".

Teaching foreign languages at the university with the usage of interactive methods is aimed at solving several problems: communicative -cognitive which improves communication skills; concrete-cognitive which considers a specific communication situation; socially-oriented which shapes and develops adequate socialization of the person.

${ }^{10}$ Бичківська Т.М. Використання інтерактивних методів навчання у процесі формування комунікативної компетенції учнів на уроках англійської мови. Науковий блог. 2017. 
Applying interactive technologies in the foreign language classroom at the university has proved very effective and motivating for students of any age group and level of mastering foreign languages. Those students who are not used interactive activities find it difficult to participate in discussions.

Interactive methods are effective techniques to reach the aim of teaching process. Interactive teaching methods can help promote the foreign communicative competence of students. The advantage of the interactive teaching methods includes the activity of the students which can be creative and communicative ${ }^{11}$.

The undoubted advantage of interactive methodology of teaching of foreign languages is its orientation to direct and indirect communication. While teaching a foreign language using this method, we should use the real situation. It's necessary to create situations that simulate real communication encouraging creativity of the students.

Among the interactive methods of teaching the most effective ones are discussion, collective situation analysis (case- study method) and role playing.

One effective kind of discussion is a "round- table" technique. Students can be seated around the table discussing problems. A lecturer has a leading role. The goal of the activity is not to find a final solution but to discuss the problem, collect as much information as possible, realize the importance of solving the problem, find ways in reaching the goals. Students can have contact with all members of discussion. It stimulates conversation and increases the number of utterances and encourages using non-verbal means of communication (miming, gestures).

A "round-table" technique can be combined with a role playing games.

Project method is a complex of research, data processing and other activities carried out by students on their own or in small groups with a view to practical or theoretical solution of the significant problem. Project-based learning involves the fundamentally different philosophy of building the educational process through students' purposeful activity in accordance with personal interest and goals.

It is obvious that the project method gives opportunities for students to express their own ideas, to identify their skills and to outline future

${ }^{11}$ Андрейко Л.В. Інтерактивні методи викладання іноземної мови: електронні засоби та дистанційні технології для навчання протягом життя. Тези доповідей міжнародної науково-методичної конференщї (Суми. 13-14 листопада 2014 р.). Суми : Сумський державний університет, 2014. С. 89-92. 
professional activity. It means that students receive an opportunity to try and test him in different areas, to reveal something intimate and interesting and focus on his desires, strengths and abilities.

Students share responsibility for his own development, the level of training for self-employment in the future. Brainstorming is a very effective kind of discussion that involves all students into the activity. A lecturer announces a topic, a goal of discussion, rules for participants and criteria for evaluating ideas. All ideas must be accepted at this stage. A lecturer encourages participation of the students. Students can improve their ideas and share them. At the next stage of the activity all ideas are estimated, grouped and the most acceptable ones are selected ${ }^{12}$.

Thus, interactive methods are a useful and fruitful component in teaching of the foreign language due to their advantages in developing communicative, cognitive, creative abilities of students and also due to the possibility to form interests of students in the learning of foreign languages ${ }^{13}$.

The role-playing game, which simulates future professional activities, contributes to the development of the skills of students. The game model of learning allows those who learn not only to feel themselves in a certain communicative role, but also to reveal their emotions, intellectual abilities, creative imagination.

We distinguish such role playing games as imitation, performance (drama) and game-competition (game). They can be identified but they mean different concepts. In the role-playing game they can play roles that they do not have in their lives.

Imitation games or situational modeling are especially useful for future professional activities.

The usage of imitations allows not only to perform actions that repeat the phenomena of the surrounding reality but also to recreate the real situations of professional life in specially created conditions. The topics for role-playing games, imitations in the teaching foreign language to

${ }^{12}$ Gorbanyova O. Interactive technologies in teaching a foreign language at higher educational establishment. International Letters of social and Humanistic Sciences. Vol. 71. Switzerland : SciPress Ltd., 2016. P. 54-59.

13 Poliakova N. Ways of using interactive methods in teaching of foreign languages at the University. The 9th International Conference on Education New Learning Technologies (3-5 July). 2017. P. 850-854. 
students may be related to their effective professional and scientific $\operatorname{activities}^{14}$.

\section{The efficiency of interactive methods in teaching of foreign languages}

The efficiency of interactive methods in teaching of foreign languages depends on many factors: individual and age characteristics of students and lecturers, their gender, professional skills of lecturers, the content of the pedagogical process, the psychophysical condition of participants and etc. It can assume that the usage of these methods of interaction does not guarantee the solution of pedagogical problems, but only creates conditions for changing the situation or moving towards the expected results.

It is commonly known that games make the learning process more educational and proficient, improve interdisciplinary relationships, connect the theory with real needs of the professional field, and skills of development that are necessary for the future specialists. The key element is the role playing that gives opportunity to form skills that are difficult to acquire foreign languages learning conditions.

Playing is the form of creation of the professional activity and modelling its typical relationships and it allows developing conditions which are necessary for training of the future specialists that are more adequate and effective.

It is commonly known that role playing makes the learning process more educational and effective, improve interdisciplinary relationships, connect the theory with real needs of the professional field, and develop skills that are necessary for the future specialists ${ }^{15}$.

The interactive methods can provide communicative orientation of the foreign language teaching which is the most successful preparation of students for future communication and interaction with those for whom the foreign language is native. They can be used for creation of conditions for the communicative activity of students which is directed on successful mastering of the foreign language speech activity and practical solution of the corresponding problem situations.

${ }^{14}$ Kravchyna T. Types of interactive methods of teaching English for technical students. Open educational e-environmental modern University. № 5. P. 140-145.

${ }^{15}$ Eltanskaya E. Types of interactive Methods in Teaching English to Students of Economics. Current Issues of Linguistics and Didactics: The Interdisciplinary approach in Humanities : the 7th International and Scientific and Practical Conference. 2017. P. 100-105. 
The essential characteristics of communication are the following: the construction of speech which can be accompanied by facial expressions and gestures; speech utterances that are purely elliptical in nature, which is possible due to the constant control of the reaction; lack of time to correct the statement and the inability to return to its beginning which causes the spontaneous speech of grammatical constructions.

Interactive methods of teaching of foreign languages give us the chance to solve some problems simultaneously. The main purpose is to develop communicative skills, to establish emotional contact with the students and to train them to work in the team.

We can admit that the usage of the interactive methods helps to avoid unreal communication, to change the forms of activity, to draw attention to the main tasks of the lesson. The introduction of interactive methods of teaching of foreign languages is the innovation process of learning foreign languages which is aimed at the formation of communicative abilities of students to develop their thinking. The most effective pedagogical tool for optimal development and professional growth of students is the communicative game.

During the communicative game students are forced to solve a lot of problem situations that contribute usage of the foreign language not only for everyday communication but also to solve professional problems. Ensuring the formation of appropriate types of speech activity, they help to implement the main function study of the foreign language in higher education and formation of professional students' communicative competence.

The learning process is much more interesting with the usage of communicative games, which is the most generalized type of teaching methods, where students learn how to perform actions spontaneously.

Communicative games form an interest in learning of foreign languages by activating mental activity and can achieve the communication goal. The communication game should not be considered as an activity of the lecturer and students.

It is concluded that interactive teaching methods are intended to put mechanisms for motivation and increasing the efficiency of teaching foreign language communication.

The advantages of using interactive methods in the process of foreign languages learning include the maximum approximation to the real conditions of professional activity, the broad autonomy of students, decision making in conditions of creative competition and the development of skills for spontaneous speech promoting the 
development of organizational skills of students, overcoming the barrier between the study of language and its practical application ${ }^{16}$.

If the lecturer wants to start the game, he informs students about the criteria for assessing their oral performances and warns that the game will be recorded on the digital video recorder so pupils could estimate extent of achievement of communicative competence of each participant of the game and their presentation. At the end of the game a video recording, a collective discussion of the results is carried out.

The analysis of games in the foreign language teaching can show that students having entered the role do not hesitate to express their thoughts in the foreign language and show creativity and independence of thinking.

Despite of the presence of some language errors, the communication can be emotional. The students demonstrate the knowledge and skills in their specialty and try to realize their professionally significant qualities as much as possible ${ }^{17}$.

The case study method is training by solving specific cases. The essence of this method is a collective analysis of the communicative situation. In the process of reviewing the cases students gain the skills of teamwork, independent solution, and independent opinion. This method involves ambiguity in the solution of the problem, which creates a challenge for discussing the reasons of proposed solutions and chooses the most appropriate ones. Therefore, the result is not only the knowledge but also professional skills and the personality and sets of values.

The case, which is viewed by the students, is usually taken from a real professional area and is supported by visual materials, statistical data, charts and graphs, descriptions of how it is viewed by different people, reports, data from the media, Internet resources, the information that allows us to understand what is described in the case.

The structure of the case has three parts: two parts are for the student and one part is for the lecturer. The subject section describes the situation and allows the students to characterize all circumstances; the information section reflects the details of the support upon which the final decision is made; and the methodical section determines the location of the case in

${ }^{16}$ Kravchyna T. Types of interactive methods of teaching English for technical students. Open educational e-environmental modern University. № 5. P. 140-145.

17 Poliakova N. Ways of using interactive methods in teaching of foreign languages at the University. The 9th International Conference on Education New Learning Technologies (3-5 July). 2017. P. 850-854. 
the structure of the course, tasks for students and pedagogical support for solving the situation.

The solution of the situations offered to the students involves a variety of analytical methods: problem-based, cause and effect, situational, prognostic and other types of predictive analysis.

The actions of students as part of the method are effective in the following succession: 1) familiarity with the situation, its content and features; 2) the allocation of the main problems, the factors and personalities that can really act; 3) offering solution concepts; 4) analyzing the consequences of the decision; 5) selecting the optimal variant, predicting consequences, an indication of the potential problems, mechanisms, prevention and solutions.

The activity of a lecturer using this method includes two phases. The first includes creating the case, formulating the questions for analysis and developing methodological software support materials for the students and their independent work. The second phase includes the classroom activities of the teacher in discussing the case, where he/she makes introductory and closing remarks, organizes discussion or presentation, supports the business atmosphere in the audience and acknowledges the contribution of students in the analysis of the situation ${ }^{18}$.

Project method is the complex of research, data processing and other activities carried out by students on their own or in small groups with a view to practical or theoretical solution of significant problems. Projectbased learning involves a fundamentally different philosophy of building the educational process through students' purposeful activity in accordance with personal interest and goals. It is obvious that the project method opens up opportunities for students to express themselves, to identify their skills and to outline future professional activity. In other words, the student receives an opportunity to try and test himself in different areas, to reveal something intimate and interesting and focus at his desires, strengths and abilities. And these activities are focused on the formation of the thinking, which is based on personal experience. They share responsibility for their own development, the level of training for self-employment in the future. Method of projects always provides the solution to some problem.

The solution to the problem involves the usage of combination of various methods and means of education and the need for the integration

18 Yakovlyeva N. Interactive teaching methods in contemporary higher education. Pacific Science Review. 2014. Vol. 16. Issue 2. P. 75-78. 
of the knowledge and skills from different fields of science, engineering, technology and creative areas. The main objectives of the project-based learning are creating the conditions in which students independently and willingly acquire the missing knowledge from different sources; learning to use the acquired knowledge to solve practical and cognitive problems; acquiring communication skills by working in different groups; developing their research skills (the ability to identify problems, gather information, observations, experiments, analysis, construction of hypotheses, generalizations); developing systematic thinking. In foreign methodical literature there are the following stages of the project: defining the project theme, problems, objectives; discussing the project structure, composing a plan; presenting language material; collecting information; analyzing and discussing data in groups with a lecturer; preparing presentation; demonstration of project results; evaluation of the project. The last phase includes not only control of mastering linguistic material and development of speech and communicative competence, but also the overall assessment of the project, which concerns the content of the project, the theme, the final result, the participation of individual students in the organization of the project work and etc. Project-based learning involves essentially the usage of the wide range of research techniques which are important for the student and for the development of the problem taking into account a variety of factors and conditions for its solution and implementation of results. Project-based learning has been widely used in many countries around the world, mainly because it allows you to integrate students' knowledge from different areas according to the solution of the problem, makes it possible to apply this knowledge in practice, at the same time generating new ideas.

We can admit that if students want to solve the problem they need not only the knowledge of the language but also the possession of a large amount of the subject knowledge, necessary and sufficient to deal with the problem. In addition, students must possess certain intellectual, creative, communicative abilities. They include the ability to work with information, with a text (highlight the main idea, search for the right information in a foreign language text), to analyze information, make generalizations, conclusions ${ }^{19}$.

19 Gorbanyova O. Interactive technologies in teaching a foreign language at higher educational establishment. International Letters of social and Humanistic Sciences. Vol. 71. Switzerland : SciPress Ltd., 2016. P. 54-59. 
The efficiency of interactive methods of teaching of foreign languages depends on the pedagogical process which can include the introduction of innovations in the traditional system of education, which provides a high degree of pedagogical creativity of the lecturer. The creative application of methods and techniques of work with students is facilitated by the implementation of the principles of the problem-solving in process of individual, pair, group or collective teaching. The defining direction is the development of students' independence, their cognitiveresearch activities, and the systematic formation of their ability to produce their point of view, assessment of life phenomena and facts, their own views, beliefs ${ }^{20}$.

The interactive learning is important for personal and professional development. Interaction helps involve students in performing activities with technical terms, and such activities can enhance vocabulary acquisition and promote the development of lexical skills. Students are able to take control of their learning process and also figure out their preferred resources with the help of interactive technology. In this way, they can choose the method to present projects and also develop important research skills for the upcoming days. Furthermore, students are able to develop their communication as well as collaborative expertise by working on shared projects or documents and this will help them significantly afterward when they matter into working ${ }^{21}$.

The main objective of teaching foreign languages is forming and developing communicative culture of students, teaching practical mastering of foreign languages. The task of the lecturer is to create conditions of the practical mastering of the language for each student, to choose such training methods which would allow each student to show his activity and creativity. Interactive methods provide the mechanisms to enable group members to explore the reasons of their work and why it is important ${ }^{22}$. They provide people with opportunities to consider and share the experiences, understandings, and commitments that brought them to the group. Being in touch with these fundamental elements is

20 Гудзяк А.М. Педагогічні інновації та трансформація ролі викладача іноземної мови. Методика викладання філологічних дисциплін у загальноосвітніх та вищих навчальних закладах Украӥни. Кам'янецьподільський : Аксіома, 2014. 100 с.

${ }^{21}$ Kravchyna T. Types of interactive methods of teaching English for technical students. Open educational e-environmental modern University. № 5. P. 140-145.

22 Стрельнікова О.В. Інтерактивні методи викладання англійської мови на неспеціальних факультетах ВНЗ. Наукові записки. Серія «Філологічна». С. 568-576. 
critically important if group members are to be invested in the group's work and motivated to make difficult decisions, resolve disagreements and apply energy and focus to their work.

It should be noted that interactive methods in teaching of foreign languages includes energetic interaction of communication. The results in active exchange of professionally significant information in foreign language, cultivates both professional and business communication skills $\mathrm{s}^{23}$.

Students of universities must be competitive in their future professional sphere.

We can admit that $\mathrm{c}$ hanging teacher-centered method into studentcentered method is a significant feature of the interactive methods of teaching. Both students and lecturers hold the idea that teacher-centered method can help students to get high marks in the exams, but it cannot improve students' knowledge of languages ${ }^{24}$. Mastering foreign languages is one of the priorities for specialists. Modern world requires strengthening general cultural foundation of education, skills development to activate personal capacity to deal with social problems.

It is obvious that there cannot be one universal scheme of organizing learning process. Lesson structure depends on goals, contents, target audience, etc. Using interactive technologies is not an objective, but it is a means of creating necessary conditions for communicatively effective learning. It encourages individuals' cooperation, self-development, improves both skills of foreign language communication and personality traits ${ }^{25}$.

\section{CONCLUSIONS}

We can acknowledge that students can control the learning process, as well as determine which resources can be used with the help of interactive technologies. Thus, they can choose methods for the presentation of projects, as well as develop the most important analytical skills in the future.

${ }^{23}$ Eltanskaya E. Types of interactive Methods in Teaching English to Students of Economics. Current Issues of Linguistics and Didactics: The Interdisciplinary approach in Humanities : the 7th International and Scientific and Practical Conference. 2017. P. 100-105.

${ }^{24}$ Yang Jie, Yaen Chee Keong. College English Teaching Methodology and Language Planning: a Pilot Study in Hetei, China. Procedia - Social and Behavior Sciences. 2014. № 118. P. 495-502.

25 Gorbanyova O. Interactive technologies in teaching a foreign language at higher educational establishment. International Letters of social and Humanistic Sciences. Vol. 71. Switzerland : SciPress Ltd., 2016. P. 54-59. 
In addition, students have the opportunity to develop their communication, as well as share experiences, working on projects and this can help them in their work.

Usage of interactive methods in teaching of foreign languages allows us to achieve proper mastering of the material by all group members, to solve various educational tasks. The lecturer becomes an independent organizer of the educational and cognitive, communicative, creative activity of students.

Interactive learning is an optimal development of both learners and those who teaches. The effectiveness of innovative approaches to teaching of foreign languages will depend on the desire and ability of lecturers to use the positive experience of students for the creative approach to the process of learning.

Interactive methods of teaching of foreign languages, which are based on a creative approach, help to use the real knowledge of students and contribute to the development and self-improvement of the educational and communicative process. There is also shown some of the interactive methods of teaching which give the foreign language lecturer the possibility to master some new techniques of communicative methods of foreign language training. The lecturer has to organize different forms of activity at the foreign language classes that is individual, pair, group and team.

Interactive methods include the dominance of one thought over another during the dialogue of students and solve complex problems based on analysis of circumstances and relevant information, participate in discussions, communicate with other people.

Situational analysis means that students, having reviewed the description of the problem, analyze the situation independently, diagnose the problem and give their ideas and solutions during discussions with other listeners depending on the nature of the presentation, situationsillustrations, situation-assessment and situation-exercises which are used. Analysis of specific situations is the most suitable method of situational analysis in educational conditions - a traditional analysis of specific situations, including a deep and detailed study of real or imitation situation. The usage of the method of analysis of specific situations allows to solve the following educational goals: the development of analytical thinking, the application of analysis in dynamics; mastering the practical skills of working with information (selection, structuring and ranking on the importance of problems); making decisions; development of modern technologies; expansion of communicative competence; formation of the ability to choose the best options for 
effective interaction with other people; stimulating innovation; increasing motivation to study problem theory.

\section{SUMMARY}

In the research the interactive methods and their efficiency in teaching foreign languages have been considered by the author.

In the modern society the knowledge of foreign languages is very important because people need global communication. One of the main directions in the development of the communication sphere is introduction of the modern information and communication technologies into the educational process.

The interactive methods of the foreign language teaching include new forms, new principles, and new approaches in teaching process. Interactive training encourages and gives learners to create comfortable condition of learning and to develop creativity, intellectual and communicative abilities. The interactive methods of teaching of foreign languages are very actual because they give the opportunity to use the active means of the communication. The learning process is much more interesting with the usage of communicative games, which is the most important type of teaching methods, where students learn how to communicate.

Interactive methods are effective techniques to reach the aim of teaching process. Interactive teaching methods can help promote the foreign communicative competence of students. The advantages of the interactive teaching methods include the activity of the students which can be creative and communicative.

Games make the learning process more educational and proficient, improve interdisciplinary relationships, connect the theory with real needs of the professional field, and skills of development that are necessary for the future specialists.

Communicative games form an interest in learning of foreign languages by activating mental activity and can achieve the communication goal. Communicative games can help students to create real situations.

The interactive methods of teaching of foreign languages give us the chance to solve some problems simultaneously. The main purpose is to develop communicative skills, cheap establish emotional contact with the students, provide with realization of educational task.

The efficiency of interactive methods of teaching of foreign languages depends on the pedagogical process which can include the 
introduction of innovations in the traditional system of education, which provides a high degree of pedagogical creativity of the lecturer.

\section{References}

1. Пишко О.П. Інтерактивні методи навчання як спосіб розвитку творчих здібностей учнів на уроках історії та правознавства. Народна освіта. 2021. URL: www.narodnaosvita.kiev.ua.

2. Eltanskaya E. Types of interactive Methods in Teaching English to Students of Economics. Current Issues of Linguistics and Didactics: The Interdisciplinary approach in Humanities : the $7^{\text {th }}$ International and Scientific and Practical Conference. 2017. P. 100-105.

3. Bakhredinovna $M$. The interactive methods and principles of foreign language teaching. International Journal on Integrated Education. 2020. Vol. 3. Issue I.

4. Ягоднікова В.В. Інтерактивні форми i методи навчання у вищій школі : навчально-методичний посібник. Київ : Персонал, 2009. 80 c. URL: www.vtei.com.ua.

5. Січкарук O.I. Інтерактивні методи навчання у вищій школі : навчально-методичний посібник. Київ : Таксон, 2006. 88 с. URL: www. studmed.ru.

6. Kravchyna T. Types of interactive methods of teaching English for technical students. Open educational e-environmental modern University. № 5. P. 140-145. URL: repository.vsau.org.

7. Андрейко Л.В. Інтерактивні методи викладання іноземної мови: електронні засоби та дистанційні технології для навчання протягом життя. Тези доповідей міжнародної науково-методичної конференції (м. Суми, 13-14 листопада 2014 р.). Суми : Сумський державний університет, 2014. С. 89-92. URL: http://essuir.sumdu.edu.ua/handle/123456789/38026.

8. Науменко У.В. Інноваційні методи навчання англійської мови у вищій школі в умовах модернізації. Молодий вчений. 2018. № 3.1 (55.1). C. 118-121. URL: lutsk-ntu.com.ua〉files12, zbirnyk_26.03.2020_0.pdfPDF.

9. Сисоєва С.В. Інтерактивні технології навчання дорослих : навчально-методичний посібник. Київ : ЕКМО, 2011. 324 с. URL: kubg.edu.ua>stories>osvitology>book_sisoeva-internet.

10.Бичківська Т.M. Використання інтерактивних методів навчання у процесі формування комунікативної компетенції учнів на уроках англійської мови. Науковий блог. 2017. URL: http://nbuv.gov.ua/UJRN/Nznuoaf_2017_64(1)_18. 
11. Gorbanyova O. Interactive technologies in teaching a foreign language at higher educational establishment. International Letters of social and Humanistic Sciences. Vol. 71. Switzerland : SciPress Ltd., 2016. P. 54-59. DOI: https://doi.org./10.18052/www.scipress.com /ILSHS.71.54.

12. Poliakova N. Ways of using interactive methods in teaching of foreign languages at the University. The 9th International Conference on Education New Learning Technologies (3-5 July). 2017. P. 850-854.

13. Yakovlyeva $\mathrm{N}$. Interactive teaching methods in contemporary higher education. Pacific Science Review. 2014. Vol. 16. Issue 2. P. 75-78. DOI: https://doi.org./10.1016/J.pscr.2014.08.016.

14.Гудзяк А.М. Педагогічні інновації та трансформація ролі викладача іноземної мови. Методика викладання філологічних дисциплін у загальноосвітніх та вищих навчальних закладах України. Кам'янець-Подільський : Аксіома, 2014. 100 с. URL: kpnu.edu.ua>sites $>2016 / 03>$ kon_3.indd_.pdf.

15. Стрельнікова О.В. Інтерактивні методи викладання англійської мови на неспеціальних факультетах ВН3. Наукові записки. Серія «Філологічна». С. 568-576. URL: www.irbis-nbuv.gov.ua>irbis_nbuv>cgiirbis_64.

16. Yang Jie, Yaen Chee Keong. College English Teaching Methodology and Language Planning: a Pilot Study in Hetei, China. Procedia - Social and Behavior Sciences. 2014. № 118. P. 495-502.

\section{Information about the author: Artemenko A. I.,}

Doctor of Philosophy in Education, Senior Lecturer at the Department of Foreign Languages Kyiv National Economic University named after Vadym Hetman 54/1, Peremohy avenue, Kyiv, 03057, Ukraine 